\title{
A közigazgatásban dolgozók továbbképzése, különös tekintettel a 2010 után megvalósult változásokra és az európai uniós operatív programokra
}

KELÖ JOHANNA ${ }^{1}$

A magyarországi közszolgálat rövid idö alatt több változáshoz alkalmazkodott. A tisztviselöi állomány folyamatosan változó szabályozási kerettel néz szembe. Ezeknek a kihívásoknak csak akkor lehet megfelelni, ha a személyzet magasan képzett és folyamatosan frissíti elméleti és gyakorlati tudását. A továbbképzés megfelelö rendszere ezért elengedhetetlen ahhoz, hogy a közszolgálatban dolgozók lépést tudjanak tartani a gyorsan változó környezettel. A tanulmány a magyar képzési rendszer meghatározó elemeire mutat rá.

Kulcsszavak: területi államigazgatás, továbbképzés, kompetenciák, személyi állomány

Further Education and Training of Public Service Staff in Particular the Changes since 2010 and the EU's Operational Programmes

The public service in Hungary had to adapt to a number of changes in a very short time. The staff is faced with a constantly changing regulatory framework. These challenges can only be met if the staff is highly qualified and constantly updating their qualifications. A sound system of in-service training is therefore crucial to keep the personnel within the public service on equal footing with the rapidly changing environment. This short paper is meant to point out the determining components of the Hungarian training system.

Keywords: public administration, further education and training, competencies, public service staff

1 Dr. Kelö Johanna jogász, Települési Önkormányzatok Országos Szövetsége (TÖOSZ), e-mail: drkelo1@gmail.com 


\section{Bevezetés}

Gajduschek György 2008-ban a következőket írta: „Gyakran hangoztatott gondolat, hogy még egy rosszabb körülmények között müködő szervezet is jól képes teljesíteni, ha a benne dolgozók motiváltak és képzettek.”2

Az elmúlt másfél évtizedben jelentősen felértékelődött az ügyféli visszajelzés, a politikai döntéshozók erőteljes igényként fogalmazták meg az államigazgatásba vetett állampolgári bizalom ${ }^{3}$ helyreállításának megvalósítását, követelményként jelent meg az államigazgatás személyi állománya számára az ügyfél érdekeinek előre sorolása, a szakértelem mellett a kölcsönösség és egyenrangúság napi rutinba ültetése. Az állampolgári elvárások közé az ügyfélbarát eljárási rend kialakítása és a hatékonyság került fókuszba, amelyet a jogalkotó igyekezett a saját eszközeivel elérni. A fenti igények gyakorlati megvalósulásának egyik pillére a tisztviselők megfelelő képzése, továbbképzése. Egyre fontosabb a humán tényező, hiszen a közigazgatás feladata az ügyfelek - magánszemélyek és vállalkozások - hatékony szolgálata.

A személyi állomány által alkalmazott ismeretek egyediek, jellegzetességük, hogy kevésbé hasznosíthatók a versenyszférában, ugyanakkor nem elhanyagolható azon jártasságok képzési rendszerbe ültetése sem, amelyek az egyéni, de általánosan használható kompetenciák bővítésére szolgálnak. Az államigazgatásban elvárt kompetenciák elsajátítását több tényező is befolyásolja, amelyek közül kiemelkedik a tisztviselői életkor. Az általánosan elfogadott ismeret szerint az életkor előrehaladtával nehezebben sajátíthatók el új készségek a tisztviselői állomány képzésekor is. Több kihívásnak is meg kell felelniük a képzőszerveknek, elsősorban azért, mert a közszférában nem tapasztalható generációváltás, a fiatalabb korosztály alig képviselteti magát ${ }^{4}$ a tisztviselői gárdában. Különösen vidéken tapasztalható az állomány elöregedése, akik az új ismeretekre nemcsak kevésbé fogékonyak, de a digitális módszerek alkalmazása különösen nagy próbatétel elé állítja jelentős részüket.

Ugyanakkor az idősebb korosztály pályaelhagyása - akár nyugdíjazás, akár más okból - számottevő tudásvesztést generál, amelynek kezelése nem várathat magára. Az 1989-1990-es rendszerváltozást követően stratégiai célként jelent meg az állam versenyképességének növelése, amelynek nélkülözhetetlen eleme a rendelkezésre álló közszolgálati humán kapacitás továbbképzése. A közigazgatási humán erőforrás ugyanakkor csak megfelelő minőségi paraméterek (felkészültség, a feladatellátáshoz szükséges kompetenciák, általános mentális állapot stb.) mentén képes érdemben megvalósítani az ügyfélbarát és hatékony szolgáltató közigazgatást. Ahhoz, hogy a jogalkotói szándék teljesüljön, szakmailag hozzáértő, kompetens személyi állományra van szükség. A tisztviselői állománynak tehát nemcsak megfelelő szakmai,

2 Gajduschek György: Közszolgálat. A magyar közigazgatás személyi állománya és személyzeti rendszere az empirikus adatok tükrében. Budapest, KSzK Rop, 2008. 7.

3 Közigazgatás- és közszolgáltatás-fejlesztési stratégia 2014-2020.

4 Csutorás Gábor Ákos: Ưj generáció a közszolgálati életpályán. Ûj Magyar Közigazgatás, 13. (2020), 2. 13. 
szakági, anyagi jogi ismeretekkel kell rendelkeznie, de olyan elsajátítandó attitűdökkel, készségekkel, képességekkel is, amelyek a munkavégzés és feladatellátás során erősítik az ügyfélorientációt, a magabiztos ügyfélkezelést, az ügyintézők irányába megfogalmazott társadalmi elvárások megjelenését.

Ahhoz, hogy a közigazgatásban megfelelően érvényesüljön a szolgáltatói szemlélet, az ügyfélbarát eljárásrend, mindenekelőtt kompetens személyi körre van szükség, amely tagjaira nézve követelmény, hogy ne csak alapos szakmai ismeretekkel, de az ügyfelek különbözőségeit is figyelembe vevő készségekkel is rendelkezzenek. Ennek a gondolatnak a mentén válik elengedhetetlenné a közigazgatás állományánál a tisztviselői kompetenciák fejlesztése. A közszektornál különösen érvényesítendő úgynevezett közjó fogalmának, a jogszabályok betartásának, az etikus magatartás vagy az ügyfelekkel való diszkriminációmentes hozzáállás, ügyintézés követelménye.

A közszolgálati tisztviselők egyéni teljesítményértékeléséről szóló 10/2013. (I.21) Korm. rendelet 4 . $\$$ e) pontja értelmezi a kompetencia kifejezést.

Eszerint a kompetencia a közszolgálati feladatok ellátásához szükséges ismeret, jártasság, készség, képesség, szociális szerep vagy érték, az én-kép, valamint az alkalmazást segítő személyiségvonások és a hatékonysági motiváció együttese. A Korm. rendelet 4. számú melléklete tartalmazza azt a 26 kompetenciát rögzítő kompetenciatérképet, amely alapján lehetőség van a tisztviselői állomány teljesítményértékelésére.

Az elvárt kompetenciák: döntésképesség, csoportok irányítása, etikus magatartás, megbízhatóság, felelösségtudat, határozottság, integritás, kapcsolattartás, konfliktuskezelés, empátia, motiválás, munkatársak fejlesztése, önálóság, rendszerben történő gondolkodás, rugalmasság, stratégiai gondolkodás, szabálytudat és fegyelmezettség, szakmai ismeretek alkalmazása, szervezet iránti lojalitás, szervezőkészség, teljesítmény-értékelés készsége, tervezőkészség, ügyfélorientáltság, változások irányítása, kezdeményezőkészség, vezetési technikák.

Jó pár éve felismerték, hogy az egyéni képességek fejlesztése kiemelkedő szerepet kell hogy kapjon a közszolgálatban: olyan állomány kialakítására és foglalkoztatására van szükség, amely természetesnek tekinti az élethosszig tartó tanulás (lifelong learning) elvét, és rendelkezik az önképzés igényével. Az 1990-es évektől bekövetkezett társadalmi és gazdasági átalakulások felerősítették a közigazgatásra vonatkozó változások szükségességét, amelyet az Európai Unióhoz való csatlakozás tovább generált. Bár a térstrukturális változás mint uniós igény nem jelent meg, ${ }^{5}$ a jogharmonizáció, a személyi állományra vonatkozó normaváltozás igen.

A 2010-es kormányváltást követően felerősödtek a közszolgálati változásokat követelő hangok, amelyek a személyügyi alapokat is módosítani szándékoztak. A közszolgálati tisztviselőkről szóló 2011. évi CXCIX törvény ${ }^{6}$ (Kttv.) első ízben teremtett egységes kategóriát a közszolgálati tisztviselői jogállás keretében közös szabályokkal (általános magatartási követelmények, személyiségi jogok védelme, egyenlő

5 Szigeti Ernő: Az államigazgatás dekoncentrált területi szervezetrendszere regionalizálásának kérdései. Budapest, Magyar Közigazgatási Intézet, 2003.

6 A Kttv. 2012. március 1-jén lépett hatályba. 
bánásmód, jognyilatkozat kérdése stb.), ugyanakkor differenciálta is a kormányzati ${ }^{7}$ szolgálati jogviszonyban állókat kormánytisztviselőkre, kormányzati ügykezelőkre, valamint a főleg önkormányzatok mellett dolgozó köztisztviselőkre, közszolgálati ügykezelőkre vonatkozóan.

Önálló közszolgálati jogviszonyként vezették be az úgynevezett állami tisztviselői jogviszonyt, amely 2016 és 2019 között a területi államigazgatásban dolgozó tisztviselőkre vonatkozott a 2016. évi LII. törvény az állami tisztviselőkről (Áttv.) alapján. A járási és fővárosi kerületi hivatalokban dolgozó kormánytisztviselőket már 2016-ban, a megyei és fôvárosi kormányhivataloknál foglalkoztatottakat 2017-ben sorolták át a korábbi kormánytisztviselői jogállásból az új állami tisztviselői jogállásba.

A területi államigazgatásban dolgozó tisztviselők jogállását a kormányzati igazgatásról szóló 2018. évi CXXV. törvény (Kit.) 2019. március 1-jével az állami tisztviselőkre nézve ismét jogviszonyváltozást eredményezett, ők ismét bekerültek a kormánytisztviselők közé. ${ }^{8}$ Tanulmányomban arra keresem a választ, hogy milyen lehetőségeket kínál a jelenleg müködő továbbképzési rendszer - nem érintem az alapés szakvizsgát - a közigazgatásban dolgozók számára, a készségeket tekintve történte kedvező irányba való elmozdulás a 2000-es évek eleje óta, milyen változások, átalakítások azonosíthatók a képzési palettában és a módszerekben.

\section{Elvárások a közigazgatás személyi állományával szemben}

Az államigazgatásban dolgozók - különösen a területi államigazgatás tisztviselỏi - nagyfokú és szinte permanens átalakulási folyamatnak voltak részesei az elmúlt három évtized során. Nemcsak a jogi környezet - anyagi jog, eljárásjog - folytonos változásaival szembesülnek, de nagy kihívást jelentenek a rendre megújuló technológiai rendszerek, példának okáért a csaknem évente megváltozó iktatási mód, illetve gyakori változás jellemzi az őket foglalkoztató szervezeti struktúrákat is. Elvárásként fogalmazódik meg ugyanakkor, hogy a tisztviselők több olyan karakterisztikus vonással rendelkezzenek, amelyek évtizedekig nem voltak sajátjai az állománynak, és amelyek elsajátításához csak az utóbbi években kapnak módszertani segítséget.

Követelményként jelenik meg a tisztviselői adaptív szemlélet is, sőt az, hogy a tisztviselő a környezetének változásait ne csak elfogadja, de azt kifejezetten pozitívan kezelje. Sokszor hangzik el, hogy a „jó közszolgálati tisztviselő elkötelezett és mentálisan is támogatja a reformfolyamatokat", a személyiségében a szakmai fejlődésre törekvés, ismerje fel kompetenciahiányosságait és azok fejlesztésére fordítson külön energiát. Az up-to-date ismeretek természetesen rendkívüli fontosságúak, és joggal várja el az ügyeit intézni kívánó állampolgár,

7 Központi és területi államigazgatásban dolgozó tisztviselők.

8 A Kit. egyidejüleg hatályon kívül helyezte az Áttv.-t.

9 ÁROP 2.2.17 „Új közszolgálati életpálya” - Köztisztviselői (kormánytisztviselői) elkötelezettség mértéke 2013. - Összefoglaló elemzés. 
ugyanakkor e kompetenciák elsajátítása nem kis kihívás, ha az állomány létszámhiánnyal küzd, vagy korszerütlen tanulástechnikai módszerekkel szembesül.

Sajnálatosan újra és újra meg kell állapítanunk, hogy a közszolgálat - különösen a vidéki hivatalokban - kevésbé vonzó a pályakezdők számára, mindezzel párhuzamosan csökken a közszolgálati munkahelyek száma. A munkaerőkorfa a törekvések ellenére tisztviselői elöregedést mutat, a közszolgálat munkaerő-megtartó képessége gyenge. Különösen igaz ez a Kit. ${ }^{10}$ hatálybalépése óta, tekintettel arra, hogy a törvény olyan jelentős változást hozott, hogy még a 36-55 év közötti tisztviselők egy része nem írta alá a kinevezésmódosítását. A nagyszámú jogviszonyról való lemondás jelentős hátrányt okozott nemcsak a hivatalok költségvetésének, gondoljunk csak a felmentési időre járó teljes bér, majd végkielégítések kifizetésére, hanem az állampolgároknak ügyfélterhei is nőttek azzal, hogy a létszámhiány miatt az ügyfélfogadási idő jelentősen rövidült, a kormányablakokban működő ügyfélfogadó munkaállomások száma csökkent, a vidékről a fővárosba vezényelt kormányablak-tisztviselők is csak átmenetileg tudták a problémát orvosolni. A Kit. következményei érintették az államigazgatás létszámgazdálkodását, a tervezhető karrierutakat, szakított a Stratégiában megfogalmazott munkaköralapú rendszerrel, és bevezette az áláshely, valamint az álláshelyhez kötött feladatkörök fogalmát. A kormánytisztviselői pálya elvesztette a stabilitás, szenioritás elv alkalmazása következtében kialakult vonzerejét. Bár a Kit. megtartotta a rugalmas illetményrendszert, a tisztviselői bér valójában elsősorban a munkáltatói szubjektumhoz kötött. ${ }^{11}$

Az NKE 2015 óta évente kiadja az úgynevezett Jó Állam Jelentést. A Jelentés a Hatékony Közigazgatás hatásterületen belül a középgeneráció részaránya a közigazgatásban dimenzióban foglalkozik a tisztviselők korosztályi megoszlásával. A jelentés megállapítja, hogy az „egészségesen és fenntarthatóan müködő szervezetrendszerben" szükségszerủ a középkorosztály stabil aránya. A 2017. évi jelentés kiemeli, hogy a magas belső mobilitási ráta veszélyeztetheti a szolgáltatási színvonal megtartását.

\section{1. táblázat: Korosztályi megoszlás}

\begin{tabular}{|c|c|c|c|}
\hline & $18-35$ év közöttiek & 36-55 év közöttiek & 56 év felettiek \\
\hline 2014 & $30,1 \%$ & $57,4 \%$ & $12,6 \%$ \\
\hline 2016 & $28,2 \%$ & $58,4 \%$ & $13,7 \%$ \\
\hline 2017 & $26,3 \%$ & $60,0 \%$ & $13,7 \%$ \\
\hline
\end{tabular}

Forrás: a szerző szerkesztése a Jó Állam Jelentés 2017, 2018, 2019 alapján ${ }^{12}$

10 A Kit. 2019. március 1-jén lépett hatályba.

11 Kelő Johanna: Változások a magyar területi államigazgatásban - szervezeti és humán erőforrás viszonyok 2010-2020. Új Magyar Közigazgatás, 13. (2020a), 3. 24.

12 Kaiser Tamás (szerk.): Jó Állam Jelentés 2017. Budapest, Dialóg Campus, 2017; Kaiser Tamás (szerk.): Jó Állam Jelentés 2018. Budapest, Dialóg Campus, 2018; Kaiser Tamás (szerk.): Jó Állam Jelentés 2019. Budapest, Nemzeti Közszolgálati Egyetem, 2019. A hozzáférhető első változatban a 2018. évi adatok nem szerepelnek. 
A 2019. évi Jó Állam Jelentés első változata szerint a trendszerủ elvándorlás csökkent, a fiatalok részaránya elérte a $26-30 \%$-ot, a középgeneráció részarányának utóbbi években tapasztalható növekedése hozzájárul a széles körü szakmai tudáson alapuló, stabil működéshez.

Gyakran azonosítható az állományban a generációs különbségek miatt bekövetkező ellentét, ugyanakkor az eltérő korosztályok együttes foglalkoztatása növeli a szervezet hatékonyságát azzal, hogy míg az idősebbek a szaktudásban, terhelhetőségben dominálnak, addig a fiatalabbak dinamizmusukkal lendületet visznek a struktúrába. A továbbképzéseknél is megfigyelhető, hogy a korosztályok máshova teszik a fókuszt. Az élethosszig való tanulás a fiatalabb korosztály sajátja, a továbbképzéseken az idősebb generáció kevésbé szívesen jelenik meg, az újszerü tanulástechnikai módszereket idegennek érezve. Ugyanakkor azt is látnunk kell, hogy a továbbképzésben kevésbé aktív rétegnél a rutinizálódás gyakori, az „így szoktuk” szemlélet hatékonyságcsökkentő szerepü. A hosszú évek, évtizedek óta közigazgatásban dolgozók szabálykövető magatartása a felgyorsult, gyakran változó világban nemegyszer gátló tényezőként hat, tekintettel arra, hogy az állomány idősebb tagjai gyakran rögzült sémákkal rendelkeznek, tudattalanul ellenállást vált ki belőlük a keretek fellazítása. Az 50 év feletti kohorszhoz tartozóknak számos esetben biztonságot adnak a szigorúbb szabályok és keretek, a változások ugyanakkor visszavetik az egyéni megoldásokat és a rezilienciát.

Ismétlődő problémaként merült fel a továbbképzésben a tisztviselői munkatehernövekedés, különösen hatásköri változás esetén, amikor a feladatok az új szervezetnél létszámemelkedés nélkül jelentek meg. ${ }^{13} \mathrm{~A}$ munkavégzés melletti tanulás nem könnyü mindenki számára, sokan megfelelő időgazdálkodás nélkül elvesznek a feladatokban.

A közigazgatás minden szegmensében megtapasztalható a tudásvesztés. ${ }^{14} \mathrm{~A}$ kollektívák új tagjai nem kapnak megfelelő támogatást, sem megfelelő helyben megszerezhető gyakorlati képzést. A vezetők rendszerszinten tévesen ítélik meg a próbaidő fontosságát, nincs kidolgozott és értő tapasztalatátadási kultúránk, ami a fluktuáció csökkenéséhez is vezethetne. A próbaidő alatt kellene a legtöbbet foglalkozni az új kollégával, folyamatos odafigyeléssel és visszajelzésekkel, hogy megértse a feladatát és megtapasztalja a szervezetben elfoglalt szerepét. Mindez vezetői feladat lenne és vezetői hiba, amelyre másik tanulmányban lesz lehetőség kitérni.

13 2015. évben a jegyzőktől a járási hivatalokhoz került az aktív korúak ellátásával kapcsolatos hatáskör, a szociális igazgatásról és szociális ellátásokról szóló 1993. III. törvény 2015. március 1-jével hatályba lépő változása révén, aminek értelmében a járási hivatalok hatósági osztályai az illetékességi területükön működő önkormányzatok több ezer iratanyagát vették át.

14 KÖFOP-2.1.5-VEKOP-16-2016-00001 A versenyképes közszolgálat személyzeti utánpótlásának stratégiai támogatása. Nemzeti Közszolgálati Egyetem, 2018. 


\section{A közigazgatási továbbképzés alakulása és jelenlegi rendszere}

A közigazgatási továbbképzés fogalmi definíciója szerint továbbképzés a tisztviselői státuszhoz kötött, ahol a tisztviselők munkájának javítása a cél, valamely új tudás, ismeretanyag, készség elsajátításával, megújításával, szükségszerủen attitűdváltozással, elsősorban az on the job (munka melletti) képzési formát preferálva, amelyre munkaidőben a munkahelyi eszközök használatával kerül sor, a gyakorlati ismeretek bővítése érdekében.

1992. július 1-jén lépett hatályba - az egységes szabályozás igényét központba helyezve - a köztisztviselők jogállásáról szóló 1992. évi XXIII. törvény, (Ktv.) amelynek 33. $\$(1)$ bekezdése rögzítette, hogy a köztisztviselők képzési, továbbképzési előírásait, 80. $\mathbb{S}(2)$ bekezdése a Belügyminisztériumot jelölte ki a képzések összehangolásáért felelős szervnek. A miniszter a feladatai ellátásának szakmai segítésére szakértő testületet hozott létre. A Közigazgatási és Közszolgálati Tanács ${ }^{15}$ mellett a Közigazgatási Továbbképzési Kollégium is müködött, amely a belügyminiszter továbbképzés-szervező, -koordináló tevékenységét támogatta. „A továbbképzési rendszer országos módszertani feladatait a Magyar Közigazgatási Intézet látja el, amely e feladatok végrehajtására létrehozta az Oktatási és Módszertani Igazgatóságát, a Közigazgatási Vezetőképzési Központot és a Kormány Közigazgatási Távoktatási Központját. A továbbképzéssel kapcsolatos tervezési és programszervezési feladatokat a megyei közigazgatási hivatalok és a meghatározott központi közigazgatási szervek - az Intézet módszertani irányítása mellett - végzik."16 1990-1999 között a közigazgatásban dolgozó állomány számára csak alap- és szakvizsgarendszer működött.

2000-től a Magyar Közigazgatási Intézet (MKI) felelt a továbbképzésekért, amelyek már nem szükültek le a csupán az alap- és szakvizsgára. Közben a tisztviselők egyre nagyobb létszámban vettek részt továbbképzéseken. Egy 2005-ben történt elemzés szerint a köztisztviselőknek már csak 18\%-a nem vett részt képzésen, a lekérdezést megelőző 3 évben, míg 35\%-uk több képzést is elvégzett. ${ }^{17} \mathrm{~A}$ képzési palettát elemezve Gajduschek megállapította, hogy a képzések tartalma nem igazodott a valós igényekhez, azok elsősorban a tudásátadásra törekedtek, frontális oktatás keretében, nem merült fel a készségek és attitűd fejlesztésének lehetősége sem, így a hatásosság és hatékonyság kérdése nem vizsgálható. ${ }^{18}$

2009-ben Szetey Gábor közigazgatásért felelős személyügyi államtitkár szüntette meg az MKI-t, feladatait jogutódja, a Kormányzati Személyügyi Szolgáltató és Közigazgatási Képző Központ (KSZK) vette át, amely 2010-től Nemzeti Közigazgatási Intézetként müködött. A rendszerváltozást követően nemcsak az egységesség igénye merült fel a köztisztviselői karral szemben, hanem hangsúlyt kapott

15 Kttv. 65. $\mathbb{\$}(1)$ bek.

16 Belényesi Emese: A képzés, továbbképzés szerepe a közigazgatási humánerőforrás fejlesztésében. 1. Mellearn Tanulmánykötet. Debrecen, 2006.

17 Gajduschek (2008): i. m. 155.

18 Gajduschek (2008): i. m. 212. 
a kiválasztás mint személyzeti politikai elem újragondolása. 2009. július 1-jétől bevezették a versenyvizsga ${ }^{19}$ intézményét. Az alapgondolat szerint a versenyvizsga a közszolgálatba való belépésre jogosított, a sikeres versenyvizsga feltételt jelent köztisztviselői álláspályázatoknál, a versenyvizsga az alapvizsga helyébe lépett. A vizsga során annak felmérése történt meg, hogy a jelölt rendelkezik a közigazgatásban való részvételhez szükséges képességekkel, készségekkel, műveltséggel, attitüddel. ${ }^{20} \mathrm{~A}$ versenyvizsga jogi hátterét a 126/2009. (VI. 15.) Korm. rendelet ${ }^{21}$ adta, a vizsgát a KSZK, valamint a Kormány általános hatáskörű területi államigazgatási szervei szervezhették. A 2010-es kormányváltást követően a versenyvizsgát 2011-ben kivezették a Ktv.-ből, a törvénymódosítás általános indokolása szerint a közigazgatási alapvizsga visszaemelésével a jogalkotó célja, hogy az eltérő szakirányú alapképzettséggel rendelkező tisztviselők egységesen rendelkezzenek a feladatellátáshoz szükséges alapvető igazgatási és jogi ismeretekkel. ${ }^{22}$

Az elmúlt közel egy évtizedben nemcsak strukturális változások történtek a magyarországi közigazgatási rendszerben, de a közszférában foglalkoztatottak továbbképzése is jelentősen módosult. 2011. október 18-án hatályba lépett a közigazgatási, rendészeti és katonai felsőoktatásról szóló 2011. évi CXXXII. törvény, amely egységesítette a hazai közszolgálati felsőoktatást a korábbi államigazgatási, honvédelmi és rendészeti felsőoktatási intézmények közös szervezeti integrációja révén, és létrehozta a Nemzeti Közszolgálati Egyetemet (NKE). A törvény az NKE-re ruházta a közszolgálat felsőfokú végzettségủ szakember-utánpótlásának biztosítását (mint közszolgálati felsőfokú képzés), valamint a közigazgatási személyzet képzésével, továbbképzésével, a közigazgatási vezetőképzéssel, a kormánytisztviselői vizsgarendszerrel kapcsolatos egyes feladatok ellátását. ${ }^{23}$

A közszolgálati tisztviselők továbbképzéséről szóló 273/2012. (IX. 28.) Korm. rendelet szerint két típusa van a közigazgatási továbbképzéseknek. Az egyik a közszolgálati továbbképzési program, amely általános közigazgatási, szakmai és vezetői ismeretek megszerzésére irányuló, a közigazgatási szakvizsgára való felkészülést moduláris rendszerben szolgáló, továbbá a jogalkalmazás javítását célzó továbbképzések, amelyek fejlesztéséről és megvalósításáról a Nemzeti Közszolgálati Egyetem gondoskodik. ${ }^{24}$ A másik a belső továbbképzés, amely a közigazgatási szerv, felsőoktatási vagy felnőttképzési intézmény által folytatott továbbképzés vagy szakmai képzés, amely

19 2007. évi LXXXIII. törvény módosította a Ktv.-t.

20 A vizsgatárgyak közé tartoztak az alkotmány- és jogi ismeretek, közigazgatás-tudományi és közigazgatási ismeretek, társadalomismeret, gazdasági és pénzügyi ismeretek, emberi jogi, etikai és adatkezelési ismeretek.

21 Lényeges kérdés volt, hogy a versenyvizsga díját a jelölt, míg az alapvizsga díját a munkáltató fizette.

22 T/2241. számú törvényjavaslat a köztisztviselők jogállásáról szóló 1992. évi XXIII. törvény módosításáról.

23 Az 1602/2014. (XI. 4.) Korm. határozat rögzítette, hogy az NKE államtudományi felsőoktatási intézménnyé alakul.

24 273/2012. (IX. 28.) Korm. rendelet 2. $\$(1)$ bek. g) pont. 
a megrendelő közigazgatási szerv számára speciális intézményi vagy munkaköri ismereteket, illetve képességeket közvetít. ${ }^{25}$

Az NKE megalakítása óta főszereplője a köztisztviselői állomány továbbképzési rendszere alakításának, orvosolandó a továbbképzésekben feltárt hiányosságokat és elmaradásokat. Fontos felismerés volt, hogy nem valósultak meg a képzéstervezésben kompetenciafejlesztésre irányuló mérések, önértékelési eszközök, a továbbképzések továbbra is inkább kínálat-, mint keresletvezéreltek ${ }^{26}$ voltak. Ugyanakkor több OECD-ország közszolgálati modelljében már az 1980-as években elindult a kompetenciamenedzsment irányzat (competency-based management, CBM). A CBM már a soft skilleket is rendszerbe emeli, mint a kommunikációt, személyiségfejlesztést, konfliktuskezelést, vitakultúrát, szervezeti ismereteket. ${ }^{27}$ 2016-ra az OECD Skills for a High Performing Civil Service elnevezésü összefoglaló tanulmányában komplex modellt állít fel, csoportosítva a közigazgatásban dolgozók fejlesztendő kompetenciáit. ${ }^{28}$

A Kormány tagjainak feladat- és hatásköréről szóló 94/2018. (V. 22.) Korm. rendelet az úgynevezett Statútum rendelet a belügyminisztert jelöli ki a közszolgálati életpálya kidolgozásáért felelős miniszternek. A miniszter a közszolgálati tisztviselők továbbképzéséről szóló 273/2012. (IX. 28.) Korm. rendelet értelmében tevékenységén belül irányítja a továbbképzés intézményrendszerét, felügyeli az NKE továbbképzési tervezéssel összefüggő, valamint módszertani és minőségirányítási tevékenységét, az NKE bevonásával felügyeli a közigazgatási szervek továbbképzési tervezési tevékenységét, a tervek végrehajtását, a közigazgatási minőségpolitikáért és személyzetpolitikáért felelős miniszterrel közösen kiadja a közszolgálati továbbképzés egységes minőségirányítási szabályzatát az NKE - a Közigazgatási Továbbképzési Kollégium (KTK) által véleményezett - javaslata alapján, és az NKE bevonásával ellenőrzi a továbbképzési programok minőségét. ${ }^{29}$

A minisztert közszolgálati továbbképzéssel összefüggő feladataiban tanácsadó testület támogatja. A Közigazgatási Továbbképzési Kollégium szakmai tanácsadó és véleményező testület. ${ }^{30}$

A közszolgálati tisztviselőkről szóló 2011. évi CXCIX törvény (Kttv.) 80. \$ (2) bekezdése szerint a közszolgálati tisztviselők (benne a különböző csoportok, így a kormánytisztviselők, 2016-2019 között az állami tisztviselők, az önkormányzati tisztviselők) továbbképzését - kivéve, ha jogszabály másként rendelkezik - az NKE biztosítja. Az NKE látja el az operatív feladatokat is, így a továbbképzési programok fejlesztését, azok megvalósítását, a ProBono rendszer müködtetését, a továbbképzési tervek számbavételét, és azok alapján jelentéseket, beszámolókat készít.

25 273/2012. (IX. 28.) Korm. rendelet 2. \$(1) bek. b) pont.

26 Gajduschek (2008): i. m. 155.

27 1989-ben Harold Schroder 11 kulcskompetenciát határozott meg, kognitív, motivációs, teljesítmény és irányítási kompetenciaterületen.

28 OECD: Skills for a High Performing Civil Service. Paris, OECD, (2017. szeptember 11.).

29 273/2012. (IX. 28.) Korm. rendelet 3. $\$$ (3) bek.

30 273/2012. (IX. 28.) Korm. rendelet 4. $\$$ (1) bek. 
A Kit. 97.\$-a rögzíti, hogy az NKE feladata a kormánytisztviselők képzésének biztosítása.

A különleges jogállású szervekről és az általuk foglalkoztatottak jogállásáról szóló 2019. évi CVII. törvény $2 . \mathbb{\$}(1)$ bekezdés $a$ ) $n$ ) pontjaiban felsorolja a különleges jogállású szerveket, például Köztársasági Elnöki Hivatal, Alkotmánybíróság Hivatala, Gazdasági Versenyhivatal, Nemzeti Választási Iroda stb., a 48. $\mathbb{S}(2)$ bekezdése pedig rögzíti, hogy e hivatalok tisztviselői állományát tekintve is az NKE végzi a továbbképzési feladatokat.

A kormányzati igazgatási szervek kormánytisztviselőinek kötelező továbbképzésről, átképzéséről, valamint a közigazgatási vezetőképzésről szóló 338/2019. (XII. 23.) Korm. rendelet a központi kormányzati igazgatási szervekre vonatkozóan szabályozza a közszolgálati továbbképzést és részletezi az NKE feladatait.

A fővárosi és megyei kormányhivatalokról, valamint a járási (fővárosi kerületi) hivatalokról szóló 86/2019. (IV. 23.) Korm. rendelet megteremtette a területi közigazgatásra vonatkozó továbbképzési rendszer kereteit.

A 273/2012. (IX. 28.) Korm. rendelet meghatározza a továbbképzési típusokat, a képzési kötelezettséget, a képzések nyilvántartásba vételét és a minősítés folyamatát, illetve a finanszírozási szabályokat. A Korm. rendelet a közigazgatási továbbképzések két típusát különbözteti meg. Az egyik az úgynevezett közszolgálati továbbképzési programok, amelyek a jogszabály szerint általános közigazgatási, szakmai és vezetői ismeretek megszerzésére irányuló, a közigazgatási szakvizsgára való felkészülést moduláris rendszerben szolgáló, továbbá a jogalkalmazás javítását célzó továbbképzések, amelyek fejlesztéséről és megvalósításáról a Nemzeti Közszolgálati Egyetem gondoskodik. ${ }^{31}$ A másik az úgynevezett belső továbbképzés, amely „közigazgatási szerv, felsőoktatási vagy felnőttképzési intézmény által folytatott továbbképzés vagy szakmai képzés, amely a megrendelő közigazgatási szerv számára speciális intézményi vagy munkaköri ismereteket, illetve képességeket közvetít”.32

A közigazgatási továbbképzések hazai rendszerében a belső továbbképzések kivételével az NKE rendelkezik szervezési és koordinációs feladatokkal.

A közigazgatási továbbképzésben az államigazgatásban, közigazgatásban foglalkoztatottak vesznek részt, így a továbbképzésben való részvétel egyben már a tisztviselői életpálya része. A közigazgatásba való bekerülésnek, bent maradásnak, valamint előrelépésnek ugyan a jogszabályokban meghatározott különböző kötelező vizsgák (alapvizsga, szakvizsga) jelentik a kritériumát, ugyanakkor a 2014. január 1-jével bevezetett egységes közszolgálati továbbképzési rendszer kötelező tanulmányi pontszámok ${ }^{33}$ megszerzését írja elő a hazai közszolgálati tisztviselők számára. A rendelet

31 273/2012. (IX. 28.) Korm. rendelet 2. $\$$ (1) bek. $g$ ) pont.

32 273/2012. (IX. 28.) Korm. rendelet 2.\$ (1) bek. b) pont.

33 A 273/2012. (IX. 28.) Korm. rendelet 9. \$ (3) bekezdés rögzíti, hogy: „A felsőfokú végzettséggel rendelkező kormánytisztviselőnek, köztisztviselőnek a továbbképzési időszak alatt legalább 128 tanulmányi pontot, az érettségivel rendelkező kormánytisztviselőnek, köztisztviselőnek legalább 64 pontot kell teljesíteni." 
meghatározza, hogy a kormánytisztviselő, köztisztviselő továbbképzése a továbbképzési időszakokban történik. A továbbképzési időszak időtartama négy év. ${ }^{34} \mathrm{~A}$ továbbképzési programok pontértékét a minősítési, valamint az irányítási folyamatban a KTK határozza meg.

Hangsúlyos tény, hogy az NKE 2015-2020 közötti időszakra vonatkozóan kilenc stratégiai területet érintő Intézményfejlesztési Tervet készített, amelyek között megjelent többek között a Közszolgálat-fejlesztés 2020, a kiváló képzés, továbbképzés, a korszerű informatika és szolgáltatások célkitűzés, és a hatékony együttműködés is. A célkitüzések közül kiemelném a hatékony együttműködést, amellyel az NKE szándékai szerint a területi közigazgatásban foglalkoztatottak senior szakemberek számára nyílt oktatói-szakértői részvételi lehetőség a továbbképzési programokban. A közszolgálat-fejlesztés 2020 célkitüzés a KÖFOP-program 2. prioritási tengelyéhez igazodva, annak keretében valósult meg.

\section{A továbbképzés stratégiai és operatív háttere}

\subsection{Magyary Közigazgatás-fejlesztési Stratégia 2011}

A közigazgatási személyügy fontos önálló fejezete volt már a 2011-ben meghirdetett Magyary Közigazgatás-fejlesztési Programnak is. A személyügyi fejezet a közszolgálati életpályák közös fejlesztését tűzte ki stratégiai célul, és a közszolgálati életpálya fontos elemeként hivatkozott a közigazgatási képzés, továbbképzés és vizsgarendszerre. A Magyary Program nyomatékosan utalt a 2012-ben elinduló Nemzeti Közszolgálati Egyetem majdani meghatározó szerepére, valamint a „kreditrendszerü, kompetenciaalapú, moduláris szerkezetű közigazgatási vezetőképző rendszerre". ${ }^{35}$

\subsection{Közigazgatás-és közszolgáltatás-fejlesztési Stratégia 2014-2020}

A Kormány 2015-ben kiadott 2014-2020 időszakra vonatkozó Közigazgatás és Közszolgáltatás-fejlesztési Stratégiájában (Stratégia) is önálló alfejezetet kapott a közigazgatási személyügy. A Stratégia a Magyary Programban meghatározott alapokra építve további újításokat deklarált, mint az átláthatóságot, az egyszerűséget. „A közigazgatás emberierőforrás-gazdálkodásának fejlesztése” címszó alatt - mint egységes közszolgálati életpályamodell, közszolgálati szolgáltatásfejlesztés, az önkormányzati emberierőforrás-gazdálkodás fejlesztése. ${ }^{36}$

A Stratégia 2020-ra tervezett átfogó célkitűzéseinek fókuszában a szervezettség, a professzionalitás és a költséghatékonyság álltak. Törekvésként bekerült a dokumentumba a Szolgáltató Állam kialakítása érdekében a stratégiai alapú, integrált

34 A 273/2012. (IX. 28.) Korm. rendelet 10. \$ (2) bek.

35 Közigazgatási és Igazságügyi Minisztérium: Magyary Zoltán Közigazgatás-fejlesztési Program (MP 11.0). (2011. június 10.). 42-47, 49.

36 Közigazgatás és Közszolgáltatás-fejlesztési Stratégia 2014-2020. 7.2. pont. 
emberierőforrás-gazdálkodás közszolgálaton belüli kiépítése. A Stratégia a tisztviselőktől elvárja a motiváltságot, a megbízható jogi, eljárásjogi ismereteken túl a változásokhoz való igazodást, az önfejlesztést, az ügyintézői kompetenciák céllal azonos, elvárt szintre emelését.

\section{3. ÁROP}

A 2007-2013-as európi uniós programozási időszakban a közigazgatási szervezeti és humán erőforrás átalakítására az Államreform Operatív Program (ÁROP) keretében 49,211 milliárd Ft jutott. Az ÁROP5 prioritási tengelyre épült az emberi erőforrás fejlesztése, a szervezeti müködés megújítása, valamint a közigazgatás teljesítményének fokozása többek között az intézményi kapacitásépítés mentén. Visszatekintve elmondható, hogy az ÁROP mögött nem volt egységes szemlélet, egymástól független fejlesztési elképzeléseket alakítottak ki. Az ÁROP prioritásai: folyamatok megújítása, szervezetfejlesztés, az emberi erőforrás minőségének javítása, a közép-magyarországi régióban megvalósuló fejlesztések, technikai segítségnyújtás a konvergenciarégiókban, technikai segítségnyújtás a közép-magyarországi régióban.

\subsection{TÁMOP}

Szintén a 2007-2013-as európai uniós programozási időszakban került sor az új munkahelyek kialakítására és az infrastruktúra-fejlesztési célok támogatására a Társadalmi Megújulás Operatív Program (TÁMOP) alapján, amely jelentős humánerőforrás-fejlesztést irányzott elő. A TÁMOP-projektek szintén 2008-2015 között valósultak meg 933,3 milliárd Ft összköltséggel, hat prioritási területen: foglalkoztathatóság fejlesztése, munkaerőpiacra való belépés ösztönzése, alkalmazkodóképesség javítása, minőségi oktatás és hozzáférés biztosítása, emberi erőforrás fejlesztése a minőségi képzés, a kutatás és innováció területén, egészségmegőrzés és a társadalmi befogadás, részvétel erősítése, az Operatív Program prioritási tengelyeinek megvalósítása a középmagyarországi régióban. A TÁMOP keretén belül is történtek képzési programok, amelyek a közigazgatást érintették.

\subsection{KÖFOP}

A Stratégiában megfogalmazott fejlesztési célok erős támogatást kaptak a 2014-2020-as programozási időszakban a Közigazgatási, Közszolgáltatás-fejlesztés Operatív Program (KÖFOP) létrehozásával, amelyet az 1004/2016. (I. 18.) Korm. határozat rögzített. A határozatban a Kormány elfogadta a program prioritási területeit, megnevezte a projekt szakmai elvárásait és az azok megvalósítására fordítható keretösszegeket, megerősítve, hogy a stratégiai célok megvalósulásához nélkülözhetetlen a kompetens tisztviselői állomány és annak fejlesztése. 
A stratégiaalkotás egyik lépéseként többszintü helyzetelemzésre is sor került, készültek összehasonlító értékelések, vizsgálták a magyar viszonyokra adaptálható nemzetközi trendeket és jó gyakorlatokat. ${ }^{37} \mathrm{~A}$ KÖFOP célja a közigazgatás hatékonyságának javítása, elsősorban az egyszerüsített közigazgatási eljárások révén, az elektronikus eljárások széles körủ bevezetése, valamint az ügyféli érdekeket előtérbe helyező szemléletváltás kialakítása érdekében a tisztviselői kar ezirányú képzése. A KÖFOP kidolgozásakor is hasznosnak bizonyulhatott a Stratégiában megtalálható SWOT-analízis, amely a közigazgatás állapotát mérve fel, több beavatkozási pontot is megjelölt. Az analízis több releváns gyengeséget is megjelölt, köztük a nem kiszámítható szervezeti változásokat, a nagyfokú fluktuációt, ami alacsony motiváltsággal párosul.

A KÖFOP 2. prioritása a szolgáltató szemlélet és az etikus működésnek a közszolgálatban történő megerősítéséről szól. Ennek mentén több projekt is tartalmazott kifejezetten kompetenciafejlesztésre irányuló képzési programokat. A KÖFOP-ot megelőzően a közigazgatási továbbképzési rendszerben a képzéstervezést nem alapozták meg a kompetenciafejlesztésre irányuló mérések, hiányoztak a kompetenciaalapú önértékelési eszközök, a továbbképzések szűk lehetőséget nyújtottak a közszolgálati kompetenciák fejlesztésére irányuló szándéknak, kevésbé voltak adottak az elektronikus oktatási környezet feltételei, valamint hiányoztak a hatékony, interaktív, élményalapú módszerek. A KÖFOP 2. prioritásának kiemelt projektjei keretében megvalósított kompetenciafejlesztő képzési programoknál törekedtek e szakmai, kompetenciaalapú módszertani igények integrálására, megjelenítésére.

A projektek közül kettőt az NKE önállóan, egyet a Miniszterelnökség a Veszprém Megyei Kormányhivatallal konzorciumban, a legkisebb költségvetésű fejlesztést a Külgazdasági és Külügyminisztérium, további egyet pedig a Belügyminisztérium valósít meg. A projektek pályázatai 2016. év folyamán elkezdődtek, a projekttevékenységek nagy része már le is zárult. A teljes fizikai zárásra több esetben eltolva kerül sor, tekintettel a 2020 tavaszán kihirdetett koronavírus-járvány okozta veszélyhelyzetre.

A KÖFOP 2.1.1. kiemelt projekt az NKE szakmai vezetése és koordinálása mellett olyan modern oktatástechnológiai háttér és képzésmenedzsment kialakítását célozta meg, amely fejlett tanulási környezetet biztosítva hatékonyan segíti a közszolgálatban dolgozó tisztviselőket a kötelező továbbképzés, valamint az egyéni fejlesztési célkitüzések, elképzelések sikeres megvalósításában. A projekt személyügyi törekvése volt, hogy széles körben fejlessze és javítsa a közszolgálatban dolgozók kompetenciaszintjét, a személyre szabott egyéni fejlesztési és tanulási módszerek segítségével. A projekt címe „A közszolgáltatás komplex kompetencia, életpálya-program és oktatás technológiai fejlesztése".

A KÖFOP 2.1.2. kiemelt projekt keretében a NKE szakmai vezetése és koordinálása keretében széles körü tudományos szintű kutatási, képzési és döntés-előkészítő tevékenység valósult meg. Az egyetem átfogó programcsomagot alakított ki a hatékony

37 Kelő Johanna: Változások a magyar területi államigazgatásban - szervezeti és humán erőforrás viszonyok. Új Magyar Közigazgatás, 13. (2020a), 2. 24. 
és stratégiai kormányzás, döntés-előkészítés és döntéstámogatás tudományos, felsőoktatási szintű támogatására. A projekt címe „A jó kormányzást megalapozó közszolgálat-fejlesztés".

A KÖFOP 2.1.3. keretében megvalósított kompetenciafejlesztés prioritása a területi államigazgatásban dolgozók képzése. A megvalósított kompetenciafejlesztő képzések széles célrendszert követtek: új ismeretek, jogszabályi változások átadása, informatikai ismeretek, mentális kompetenciák erősítése. A projekt címe „A területi államigazgatási szervek humán erőforrásának fejlesztése”.

A KÖFOP 2.1.4. projekt önálló külügyi programként valósult meg, tekintettel arra, hogy a külügyi feladat- és közszolgáltatáshoz szükséges speciális tudás, képességek, kompetenciák szükségesek, ezért a minisztérium a továbbképzést sajátjaként kívánta megvalósítani. A projekt címe „A Külgazdasági és Külügyminisztérium humánerőforrás-gazdálkodásának és belső képzési rendszerének fejlesztése".

A KÖFOP 2.1.5. projekt legfontosabb célja a közszolgálati pálya vonzóvá tétele, a pályakezdők beillesztését és pályán maradását szolgáló hatékony humánerőforrásgazdálkodás eszközrendszerének kialakítása, a szervezeti és személyes közszolgálati kompetenciák fejlesztése. További célként fogalmazták meg a közszolgálat tervszerü személyi utánpótlásának biztosítását is. A projekt címe „A versenyképes közszolgálat személyzeti utánpótlásának stratégiai támogatása”.

\section{Az elmúlt évek továbbképzéseinek szakmai eredményei, nehézségei, adatai}

\subsection{Továbbképzések szakmai eredményei}

Ellentétben a hagyományos képzési módszerekkel a kompetenciaalapú oktatás nem elsősorban a reprodukálható tudás megszerzésére fókuszál. A tudásmegszerzés célja az új ismeretek elsajátítása mellett az adott kompetencia kialakítása, változása. A kompetenciaalapú továbbképzési rendszerben a tanulás a személyiségben bekövetkező kompetenciaváltozáshoz vezető gyakorlatok elvégzésének sora. ${ }^{38} \mathrm{~A}$ továbbképzés hatékonyságát kedvezően befolyásolta és befolyásolja a KÖFOP-projekt, amelynek 2. prioritási tengelyében, az NKE továbbképzési programjaiban megkülönböztetünk elsődleges és másodlagos célcsoportokat. Elsődleges célcsoportnak számítanak a kompetenciafejlesztésbe bevonni kívánt ügyintézők, vezetők, valamint azok a már említett senior szakemberek, akik a továbbképzést követően mentorként, tutorként, trénerként működnek közre saját hivataluk állományának fejlesztésében. Másodlagos célcsoportjai a képzéseknek az ügyfelek, vállalkozások, egyéb partnerek, akikre a továbbképzett állomány hatással van ügyintézésük folyamán. Az utánpótlás biztosításának pedig egyik lehetősége a megfelelő továbbképzés.

38 Kisfaludy László - Orosz Lajos: Alapvető tudnivalók az állami és a közszolgálati tisztviselői továbbképzésben közremüködő oktatók, vizsgáztatók és szakértók részére. Nemzeti Közszolgálati Egyetem, 2018. 
Egyik legfontosabb technikai és egyben módszertani eredménynek tekinthetjük a ProBono felület létrehozását, amelyet ÁROP-ból ${ }^{39}$ fejlesztettek. A felület használatával megvalósul a tanulási esélyegyenlőség, a vidéki, NKE-től távol lévő hivatalok tisztviselői is részt vehetnek a képzéseken komolyabb többletidő- és energiaráfordítás nélkül.

A képzések kiválasztásánál megjelent az egyéni igényeken alapuló képzési lehetőség, amikor a tisztviselő a jogszabályi alapon kötelező képzéseken túl, saját fejlesztendő kompetenciáit felismerve választ képzéseket. Mindenképpen hasznos, ha összhangban van az egyéni igényü képzés a szervezet érdekeiben álló képzéssel, és a tisztviselő elöírt továbbképzési keretében a képzések tudatosan egymásra épülnek.

Már egy évtizeddel ezelőtt megfogalmazták, hogy a specifikus ágazati-szakmai ismereteken túl szükség lenne egyéni készségek fejlesztésére, különösen az ügyfélszolgálati pontokon foglalkoztatott tisztviselői réteg számára. Ezen igény jelent meg a kompetenciakataszter meghatározásakor. Az NKE képzési palettája szélesedett, a frontális képzések helyét egyre inkább átveszik az e-learning-képzések, a tréningek és a vegyes, úgynevezett „blended” jellegű megoldások. A fejlesztések révén sokszínű képzési spektrumot dolgoztak ki és alkalmaznak. Az e-learning-képzések nélkülözik a személyes megjelenés kötelezettségét, emiatt népszerűségük emelkedik, hiszen kiküszöböli a képzésszervezés logisztikai problémáit, jól megválasztott kép- és hangminőséggel, a vizuális újdonságokra építve, kedveltségük folyamatosan nő. Ráadásul az e-learning-tananyagok az elmúlt években bővültek videóprezentációs e-tananyagokkal, élőszereplős történetek beágyazásával, oktatófilmekkel, egyéb szimulációs helyzetgyakorlatokkal. Ezek az újítások segítik az oktatni kívánt ismeretek feldolgozását és mélyebb beépülését. Fontos újítása a képzéseknek a tutorált e-learning-képzési forma, amely nagyobb létszámú 15-25 fős csoportok egyidejű oktatását teszi lehetővé a virtuális online térben. A hallgatók személyes támogatásban részesülnek a tutortól, általában esettanulmányok feldolgozása során.

Tapasztalataim szerint ${ }^{40}$ azonban a jelenléti képzések nem válthatók ki teljesen e-learning-programokkal. A személyes jelenléti képzési formák, nagyobb hatékonysággal keltik fel a hallgatók figyelmét, tartják fenn a résztvevők motivációját, és a gyakorlatban is hasznosítható ismeretet adnak. Egyre elterjedtebb, közkedveltebb sajátos képzési forma a tréning. Az élményalapú tanulási verzió - csoportmunka által elvezet az „ahaélmény” megéléséhez, különösen akkor, ha a csoport megfelelö létszámú, és az elsajátítandó kompetenciákhoz a tréner olyan gyakorlat feldolgozását kéri, amelyben a résztvevői aktivitás emelkedik. A tréningmódszernél nem történik frontális oktatás, nem a tréner tanít, a csoportban lévő tudás, ismeret a csoporttagok konstruktív szereplésével kerül felszínre. Különböző közegből érkező hallgatók esetén figyelhető meg, hogy az eltérő alaptudású csoporttagok egymással megosztott tapasztalatai az esettanulmányok, helyzetgyakorlatok újszerű, kreatív megoldását

39 ÁROP 2.2.5-2008-0001 Humánerőforrás-gazdálkodás központi Közigazgatás programon belül.

40 A szerző közszolgálatikompetencia-trénerként dolgozik. 
eredményezik. Fontos látni, hogy a tréning a konstruktivista tanulási módok ${ }^{41}$ közé tartozik, és mint ilyen, rejtett tantervü, a tréner a csoporthoz, az elsajátítandó kompetenciához igazított forgatókönyv alapján tartja meg a programot, amelyben a hagyományos előadó-hallgató, tanár-diák viszonyrendszer elemei nem érvényesülnek, így a közvetlenebb hangulat is hozzájárul az egyéni kiteljesedéshez. Számos tematikus tréning került be a közszolgálati kínálatba - stresszkezelő tréning, érzékenyítő tréning -, amelyek az államigazgatásban dolgozó ügyintézők számára is elérhetők. A tréningekhez "train the trainer" módszerrel képzett trénereket alkalmaznak. A specifikuma e trénerképzésnek, hogy adott szervezeti egység munkatársa közül kerültek ki azok a tisztviselők, akik a későbbiekben belső képzőként végeznek tréneri feladatokat. Ezzel párhuzamosan egyre inkább megtaláljuk a képzési programokban a legkorszerübb úgynevezett gamifikációs megoldásokat. Különösen örvendetes ez a tendenciaváltozás, tekintettel arra, hogy „game” megoldások alkalmazása motiváló, erősítő, és segít az élményalapú tanulásban.

Megjelent az „on the job” képzési forma is, amelyre jellemző, hogy közvetlenül a tisztviselő munkahelyén valósulnak meg a tisztviselő által használt és kezelt szakrendszerek, müködési folyamatok megismerése, azok gyakorlati szintű használata.

\subsection{A továbbképzési rendszer nehézségei}

Természetes, hogy a továbbképzések kidolgozásakor a jogszabály kötelezően elvégzendő képzéseket is meghatározhat. Fontos volna azonban, hogy a kötelező képzések ne fulladjanak unalomba és minél nagyobb mértékben hasznosuljanak a tisztviselőknél. Az Európai Unióhoz való csatlakozást követően a teljes tisztviselői állomány kötelező képzése köré tartozott az EU-s képzés, miközben esélyes volt, hogy az állomány többsége közvetlen módon nem, vagy alig kerül kapcsolatba a közösségi intézményekkel. ${ }^{42}$ Fontos, hogy a továbbképzési programkínálatban helyet kapó képzések találkozzanak a tisztviselők tetszésével, mivel a népszerütlen programok hosszú távon demotiváló hatással járhatnak, roncsolva a teljes továbbképzési rendszer tisztviselői megítélését. ${ }^{43}$

Az e-learning módon teljesíthető képzéseken a tapasztalatok szerint a vizsgák esetenként nem tükrözik a valóságot. A gyakorlatban a tisztviselők azokat zömében csoportosan végzik el, tekintettel arra, hogy a munka melletti tanulás, képzés nem mehet az ügyintézés rovására, így az ügyintézők a képzés elvégzésére és a vizsgára is csak minimális időt tudnak fordítani, így azonban az egyéni ismeret és beépülés nem feltétlenül mutatja a valóságot. ${ }^{44}$

41 Kisfaludy-Orosz (2018): i. m. 26.

42 Gajduschek (2008): i. m. 210.

43 Gajduschek az ANOVA módszerrel megvizsgálta a tisztviselők „EU-tudását”, és összevetette az EU-s képzést elvégzők ismereteit azokkal, akik a képzést nem végezték el. Megállapította, hogy az ismeretkülönbség minimális.

A szerző ezirányú személyes tapasztalatai szerint. 
A „train the trainer” módszer nagyszerü lehetőséget kínál arra, hogy a tréningek nyújtotta ismeretek több csoportban, akár évenként is ismétlődhessenek. Az utóbbi évek jelentős átalakításai, különösen a Kit. bevezetését követően jól képzett trénerek, mentorok is távoztak a közigazgatásból, akik pótlása nem könnyü, és hiányuk erőteljesen érezteti majd a hatását, nemcsak a már igazolódott tudásvesztés miatt, hanem a trénerek képzésére fordított ismételt költségek miatt is.

Számos esetben történik még tételesjogi ismeretátadás képzések helyett, ami több szempontból is káros. A gyakran változó jogszabályi környezetben az elsajátított anyag gyorsan elavul, így az ilyen jellegủ képzés a képzési céllal ellentétes. Persze új jogszabály bevezetése esetén fontos lenne a joganyag gyakorlati alkalmazására való felkészítés, azonban ez alig, vagy a hatályba lépést követően jóval később történik, amire példa az Ákr. „képzés”, amelyre több megyei kormányhivatalban csak január végén, februárban került sor annak ellenére, hogy az eljárásjogot szabályozó törvény 2018. január 1-jével lépett hatályba.

Gyakorló trénerként sajnálatosnak tartom, hogy a többnapos tréningeket megszüntették. Természetesen értem az intézkedés költséghatékonyságát, azonban módszertani szempontból a megoldás nem oktatás- és hallgatóbarát. Nehezíti a tréningek dinamikáját, szűkíti az átadható információt, nincs elég idő a csoportdinamikára, megtöri a tréning ívét. A rövidített képzés során nincs lehetőség a kérdések, tapasztalatok, reflexiók megosztására, amelyből a csoporttagok nagyon sokat tanulhatnak.

A tapasztalatok azt mutatják, hogy az elégedettségi visszajelzések száma eltörpül a képzésen részt vevők számához képest. Álláspontom szerint nem alakult még ki az egészséges feedback mechanizmusa, hiszen a mindennel 100\%-ban elégedett hallgató valószínűleg jóval kevesebb, mint az ilyen tartalommal kitöltött elégedettségi kérdőívek és más adatfelvétel. Ennek oka többféle lehet, a tisztviselőkben még mindig élő megfelelési kényszer is vezethet ide, de akár az a szemlélet is, hogy sokan közülük nem bíznak abban, hogy a konstruktív kritikák változásokat generálhatnak. Az elégedettségi kérdőívek anonim jellege ugyanakkor hozzájárul a képzési tapasztalatok valós értékeléséhez, de ebben is szükség van további kulturális változásokra. Ugyanakkor fontos lenne a képzésben részt vevőknek tudni és elfogadni, hogy az elégedettségi teszt kitöltése számukra is lehetőség, a képzés szervezőjének, az oktatási program megvalósításáért felelős személynek pedig nélkülözhetetlen. Épp ezért az önkéntest visszajelzést felválthatná a kötelező jellegű értékelés, amelynek elmaradása a képzési részvételt igazoló oklevél kiadásának elmaradását vonhatná maga után.

További nehézség, hogy a hivatalok nem minden esetben támogatják a tisztviselők továbbképzési terveit, vonakodva vagy nem kötnek tanulmányi szerződést, illetve a szabadidő, vagy csak a szabadság terhére végezhetik a tisztviselők el az őket érdeklő képzéseket. 


\subsection{Továbbképzés számokban}

2. táblázat: Továbbképzés számokban

\begin{tabular}{|l|r|r|r|}
\hline & 2018 & 2017 & 2016 \\
\hline $\begin{array}{l}\text { egyéni képzési tervek tisztviselőkre } \\
\text { bontva }\end{array}$ & 80900 & 71185 & 82977 \\
\hline $\begin{array}{l}\text { továbbképzési programjegyzéken } \\
\text { szereplő programok száma/NKE által } \\
\text { nyújtott képzés }\end{array}$ & $2354 / 470$ & $2374 / 455$ & $2186 / 330$ \\
\hline teljesített e-learning-képzések (db) & 121252 & 207316 & 69123 \\
\hline $\begin{array}{l}\text { jelenléti típusú képzési programban } \\
\text { résztvevők (fó) }\end{array}$ & 4972 & 7254 & 9321 \\
\hline összrésztvevői szám (fö) & 75122 & 69461 & 69368 \\
\hline
\end{tabular}

Forrás: a szerző szerkesztése a Jó Állam Jelentés 2017, 2018, 2019 alapján

\section{Pozitív gyakorlati példák}

Önkényesen kiemelve röviden elemzek a KÖFOP 2. prioritási tengelyében megvalósult néhány képzést.

\subsection{KAB-képzés}

A KÖFOP-2.1.3-VEKOP-15-2016-00002 program a területi államigazgatási szervek humán erőforrásának fejlesztését helyezte középpontba.

A kormányablakok (KAB) rendszere jelentős intézményi újításként értékelhető. A bürokráciacsökkentés és ügyfélbarát ügyintézés alapja az egyablakos rendszer lett. A kormányablakokat a korábban jegyzői irányítás alatt lévő okmányirodai alapokon

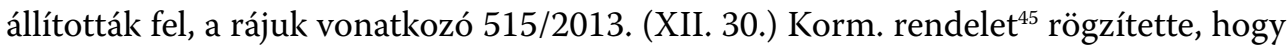
a járási hivatalok integrált ügyfélszolgálatot, úgynevezett kormányablakot működtetnek. Számuk járásonként eltérően alakult, azonban 2015. év végére már minden járásban legalább egy kormányablak működött. A „klasszikus” okmányirodai ügytípusok folyamatosan bővültek különböző humán szakigazgatási hatáskörökkel (nyugdíjigazgatáshoz kapcsolódó hatósági feladatok, családtámogatások stb.).

A KÖFOP-2.1.3. projekt az állami tisztviselői állományra fókuszált, többek között a kormányablakokban dolgozókra mint kiemelt ügyintézői körre. Az állami tisztviselők képzését, továbbképzését a 321/2016. (X. 27.) Korm. rendelet ${ }^{46}$ szabályozta, hangsúlyozva a kormányablakokban dolgozó ügyintézők képzésének prioritását.

45 Hatályát vesztette 2019. április 24-től, helyette hatályba lépett a 86/2019. (IV. 23.) Korm. rendelet.

46 Hatályát vesztette 2019. április 24-től, helyette hatályba lépett a 86/2019. (IV. 23.) Korm. rendelet. 
A KÖFOP-programok mindegyike előzményként tekintett az előző tervezési ciklusban az ÁROP forrásaiból megvalósult közigazgatási fejlesztésekre.

Az ÁROP-1.2.9-2012-2012-0001 Ügyfélszolgálati élethelyzetek, eljárások kidolgozása programot a Közigazgatási és Igazságügyi Minisztérium kivitelezte, amelynek keretében a kormányablakokat kiszolgáló, országosan egységes tudásbázist alkottak meg és alakítottak ki, valamint egységesítették az azok működtetéséhez szükséges folyamatokat.

Az ÁROP-2-2.20-2013-2013-0001 program a területi államigazgatás átalakításához kapcsolódva a kormányablakok munkatársainak képzését végezte, nyomatékot adva az országosan egységes, minőségi ügyintézés követelményének. Fontos megjegyezni, hogy az ÁROP-2-2.20-2013-2013-0001 programban való részvétel kizárta a KÖFOP-2.1.3-VEKOP-15-2016-00002 programban való képzést. Ennek biztosítása részben a központi képzésszervezők feladataként jelent meg, részben a hallgatók személyes írásos nyilatkozata alapján történt.

$\mathrm{Az}$ ÁROP képzési rendszert érintő tapasztalatokat építő jelleggel beépítették a KÖFOP programokba, így a továbbképzések fejlesztésének két irányt szabott a KÖFOP. Először is hangsúlyozta a kormányhivatali belső képzések hatékonyabbá, rugalmassá tételét, képzésszervezési módszerek, eljárásrendek, belső szabályzók kialakításával, másodszor, igazodva a Kit. által bevezetett feladatkör mint humánerőforrás-szervezési fogalom okozta változásokhoz, az ezekhez idomuló akár ad hoc módon felmerülő képzési igényekre, azok felmérését és kielégítését helyezte a középpontba.

A szakismeretet, rutint, készségeket fejlesztő képzések közül a kormányablakügyintézők képzése 5 ütemben, 2016 harmadik negyedévétől zajlott. A képzést a kormányablakokban dolgozó szakügyintézők és ügyintézők kötelező képzéseként írták elö, azzal, hogy a rájuk vonatkozó továbbképzési kötelezettség kezdetétől számított 1 éven belül a sikeres ügyintézői oklevél megszerzése a tovább foglalkoztatás feltétele.

Valójában a KAB-képzések két KÖFOP-projekthez is kapcsolódnak. A KÖFOP -2.1.1. projekt kapcsán az NKE által kifejlesztett központi ProBono felületen végezték az állami tisztviselők a képzés e-learning-tananyagait, amely tartalmazta a hatósági eljárásra vonatkozó joganyagot, ügyfélszolgálatot, ügyfélbarát szolgáltatást segítő soft skillek elsajátítására vonatkozó ismereteket, és az e-közigazgatás alapjait. A KÖFOP-2.1.3-VEKOP-15-2016-00002 projekt terhére az úgynevezett Munkába Illesztő Képzések valósultak meg, ahol az okmányirodai és szakigazgatási szakrendszerekkel, végfelhasználói környezettel ismerkedtek a résztvevők, valamint tovább folytatódtak az egyedi ügyek és élethelyzetek szimulációi, az ön- és ügyfélismereti jelenléti képzések, amelyek az érzékenyítésre és a munkahelyi stresszkezelésre fókuszáltak belső képzések keretében. A trénereket előzetesen a már említett train the trainer módszerrel készítették fel a tréningtartásra. A szabályozás szerint a fơvárosi és megyei kormányhivatalok munkatársait jelölték ki, és ők végezték el az NKE speciális trénerképző programját. A „képző képzése” módszerrel lehetőség nyílik arra, hogy projekt lezárását követően is megtarthatóak legyenek a képzések, tekintettel arra, hogy a trénerek az oktatáshoz szükséges kompetenciákkal már rendelkeznek. 
Míg az ÁROP-projektek alatt csak elméleti ismeretek átadására került sor, a későbbiekben már demóanyagok is megjelentek, amelyek a különböző okmánykészítési folyamatokat is bemutatták. A KAB III. ütemtől az ARCAD szakrendszer is felállt, amely a továbbképzésben részt vevők számára gyakorló, valamint szimulációs feladatokat is tartalmazott, amelyek nagyban segítették az elmélet beépülését. A képzésszervezők a KAB III. ütemtől nagyobb hangsúlyt fektettek a felnőttoktatásban jártas előadók, trénerek foglalkoztatására, így a frontális oktatást igénylő elméleti oktatás is élvezetesebbé, hatékonyabbá vált. A IV-V. ütemben már rutinszerủen használatba került az okmányirodai szakrendszerek használata is, ami magabiztosabbá tette a képzést elvégzőket, és sikeresebb vizsgákat eredményezett. ${ }^{47} \mathrm{~A}$ KAB-képzés mindenképpen pozitív példa a részvevői és oktatói visszajelzések alapján átformált, megújított képzésre.

\subsection{Mentorprogram}

Az általános közigazgatási rendtartásról szóló 2016. CL. törvény ${ }^{48}$ (Ákr.) bevezetésével megváltozott a hatósági ellenőrzés rendszere, vonatkozó szabályainak alkalmazásával a 315/2016. (X. 20.) Korm. rendelet bevezette az egyszerüsített ellenőrzés fogalmát, ami munkafolyamatba épített hivatalbóli vagy bejelentésre történő ellenőrzést jelent. Olyan területek esetén végzik ezeket az ellenőrzéseket, ahol átfogó, speciális képzést követően az ügyintézők képesek a kötelezett ügyféli tevékenység több oldalról történő ellenőrzésére, például építésfelügyeleti, fogyasztóvédelmi, munkaügyi, munkavédelmi, élelmiszer-biztonsági, népegészségügyi területen. Az ellenőrzések célja a kormányrendeletben ${ }^{49}$ megjelölt esetleges jogszabálysértések ellenőrzése és azok jogkövetkezményének alkalmazására irányuló eljárás lefolytatása. Az egyszerüsített ellenőrzésekre vonatkozóan két képzési típust valósítottak meg. A hivatalok létszámát alapul véve meghatározott számú mentort képeztek a MOBILPROG ${ }^{\mathrm{M}}$ képzés során, akik mentorként, belső oktatóként követték és segítették saját, hatósági ellenőrzést is végző hivatali kollégáikat az új szabályok elsajátításában a MOBILPROG keretében. A mentori megoldás sokban hasonlít az e-learning-képzéseknél megismert tutorok szerepvállalásához, viszont módszertani szempontból kiterjedtebb támogató jelenlétet valósít meg.

\section{7. Összegzés}

A közigazgatás alapvető feladata és küldetése, hogy zavartalan igazgatási, hatósági hátteret biztosítson a gazdasági és társadalmi alrendszerek számára. Ebben a folya-

47 A szerzőnek gyakorlati tapasztalatai vannak a képzésekről, 2013-2019 között Járási Hivatalvezetőként dolgozott, valamint a KAB-képzésben részt vevő ügyintézőknek honosítási, hatósági, szociális, állampolgársági igazgatási ismereteket oktatott.

48 Az Ákr. 2018. január 1-jével lépett hatályba.

49 86/2019. (IV.23.) Korm. rendelet a fővárosi és megyei kormányhivatalokról, valamint a járási (fővárosi kerületi) hivatalokról 4. sz. melléklet. 
matban a közszolgálati személyügy és humánerőforrás-fejlesztés stratégiai fontosságú kérdés. A személyügyi fejlesztések irányainál kiemelkedő - különösen a képzés, továbbképzés területén - a vállalati szektorból átvett kompetenciaalapú menedzsment megközelítés. A fejlett OECD-országok már az 1980-as évek óta alkalmazzák a közigazgatási továbbképzésben - hazánkban évtizedekig kevésbé fontosnak tartott - soft skillek oktatását, mint a kommunikáció, személyiségfejlesztés vagy csoportdinamika.

Az utóbbi évek közszolgálati továbbképzési rendszerében ugyanakkor jelentős eltérések és ezáltal eredmények láthatóak. A kompetenciaalapú megközelítés erőteljesen jelenik meg a hazai továbbképzésben is.

Az új módszertani eszközök kedvezően befolyásolták a tanulási esélyegyenlőséget, azáltal, hogy a helyileg távolabb dolgozó tisztviselők azonos ismeretekhez juthatnak az e-learning alapú képzések és módszertani eszközök révén. A klasszikus jelenléti alapú frontális oktatás mellett egyre inkább előtérbe kerültek a korszerủ digitális, tréning jellegű képzési programok, ezek ingergazdagságukkal motiválják a hallgatókat. A továbbképzésért felelős szervek próbálnak olyan képzési kínálatot nyújtani, amely valóban közelít a tisztviselők egyéni igényeihez. A rendszerszintű tanulás egyaránt szolgálja az egyén és a szervezet érdekeit, különösen, ha a kínálati oldalon megjelennek azok a képzések, amelyek inspirálják és hatékonyan megszólítják a tisztviselőket.

A kompetenciaalapú megközelítés különösen hangsúlyos volt a Közigazgatásés közszolgáltatásfejlesztési Operatív Program (KÖFOP) 2014-ben indult képzési, továbbképzési fejlesztéseiben. Ezek érintették az állami és önkormányzati szektorokban dolgozó tisztviselőket, de közvetve a pedagógusokat vagy az európai uniós források révén érdekelt egyéb más dolgozói csoportokat.

Bár az e-learning-képzések több előnyét is ismerjük, a hallgatók elkülönülése, a személyes kommunikáció, valamint a szociális aktivitás hiánya időnként károsan hat a részvételi motivációkra. A jelenléti képzéseknek előnye, hogy pozitív irányba terjesztheti ki a munkatársi kapcsolatokat, a képzéseken való részvétel az együttmüködések alapja lehet. Mások gondolkodásmódjának, szemléletének megismerése ugyanakkor tágítja az egyéni tudásalapot, a folyamatosan frissített információ és szaktudás lassítja az ismeretek amortizálódási idejét. Különösen igaz ez, ha az oktató vagy tréner a személyiségével képes magával ragadni a csoporttagokat, visszajelzései ösztönöznek és kedvezően hatnak az önismeretre is. A több területről érkezett hallgatótársakkal való összecsiszolódás, az ismeretlen „játszótársakkal” történő együttműködés a saját hivatali közösségre is kedvező hatást gyakorolhat.

A tisztviselők egyéni igényének kielégítését szolgáló képzések hozzájárulnak a lemorzsolódás csökkenéséhez, amely hosszú távon egybevág a szervezeti érdekekkel.

\section{Irodalomjegyzék}

Belényesi Emese: A képzés, továbbképzés szerepe a közigazgatási humán eröforrás fejlesztésében. 1. Mellearn Tanulmánykötet. Debrecen, 2006. Online: http://real.mtak.hu/82366/1/A_kepzes_ tovabbkepzes_szerepe_a_kozigazgatasi_humaneroforras_fejleszteseben_u.pdf 
Csutorás Gábor Ákos: Új generáció a közszolgálati életpályán Ưj Magyar Közigazgatás, 13. (2020), 2. 10-21.

Gajduschek György: Közszolgálat. A magyar közigazgatás személyi állománya és személyzeti rendszere az empirikus adatok tükrében. Budapest, KSzK ROP, 2008.

Hazafi Zoltán: Humánorientációjú szervezetfejlesztés. Új Magyar Közigazgatás, 13. (2020), 3. 1-9. Kaiser Tamás (szerk.): Jó Állam Jelentés 2017. Budapest, Dialóg Campus, 2017. Online: https://joallamjelentes.uni-nke.hu/kiadvanyok/jo-allam-jelentes-2017/

Kaiser Tamás (szerk.): Jó Állam Jelentés 2018. Budapest, Dialóg Campus, 2018. Online: https://joallamjelentes.uni-nke.hu/kiadvanyok/jo-allam-jelentes-2018/

Kaiser Tamás (szerk.): Jó Állam Jelentés 2019. Budapest, Nemzeti Közszolgálati Egyetem, 2019. Online: https://joallamjelentes.uni-nke.hu/kiadvanyok/jo-allam-jelentes-2019-elso-valtozat/

Kelő Johanna: Változások a magyar területi államigazgatásban - szervezeti és humán erőforrás viszonyok 2010-2020. Új Magyar Közigazgatás, 13. (2020a), 2. 22-29

Kelő Johanna: Változások a magyar területi államigazgatásban - szervezeti és humán erőforrás viszonyok 2010-2020. Új Magyar Közigazgatás, 13. (2020b), 3. 14-20.

Kisfaludy László - Orosz Lajos: Alapvető tudnivalók az állami és a közszolgálati tisztviselői továbbképzésben közreműködő oktatók, vizsgáztatók és szakértők részére. Budapest, NKE, 2018. Online: https://nkerepo.uni-nke.hu/xmlui/bitstream/handle/123456789/7136/Alapvet\%20\%20 tudnival\%F3k\%20az\%20\%E1llami\%20\%E9s\%20a\%20k\%F6zszolg\%E1lati\%20tisztvisel\%20i\%20 tov\%E1bb.pdf;jsessionid=DFA4575917B86504A54165E22F097557? sequence=1

Schroder, Harold: Managerial Competence: The Key to Excellence. Dubuque, Iowa, Kendall \& Kent, 1989.

Szabó Tamás: Smart Leader önkormányzati vezetőképző program. Új Magyar Közigazgatás, 13. (2020), 3. 42-44.

Szigeti Ernő: Az államigazgatás dekoncentrált területi szervezetrendszere regionalizálásának kérdései. Budapest, Magyar Közigazgatási Intézet, 2003. Online: www.terport.hu/webfm_send/339

\section{Jogforrások}

273/2012. (IX. 28.) Korm. rendelet a közszolgálati tisztviselök továbbképzéséről

86/2019. (IV. 23.) Korm. rendelet a fővárosi és megyei kormányhivatalokról, valamint a járási (fővárosi kerületi) hivatalokról

\section{Internetes források}

OECD: Skills for a High Performing Civil Service. Paris, OECD, 2017. Online: https://doi. org/10.1787/9789264280724-en

Kaiser Tamás (szerk.): Jó Állam Jelentés 2019 - első változat. Budapest, Nemzeti Közszolgálati Egyetem, 2019. Online: https://joallamjelentes.uni-nke.hu/kiadvanyok/jo-allam-jelentes-2019-elsovaltozat/

KÖFOP-2.1.5-VEKOP-16-2016-00001 A versenyképes közszolgálat személyzeti utánpótlásának stratégiai támogatása. Nemzeti Közszolgálati Egyetem, 2018. Online: https://fejlesztesiprogramok.uni-nke.hu/document/fejlesztesiprogramok-uni-nke-hu/K\%C3\%96FOP\%202-1-5\%20 Mentor\%20rendszer.pdf 
Közigazgatás- és közszolgáltatás-fejlesztési stratégia 2014-2020. Online: www.brdsz.hu/images/cikkek/2018/kozigazgatas_feljesztesi_strategia_2015.pdf

Közigazgatási és Igazságügyi Minisztérium: Magyary Zoltán Közigazgatás-fejlesztési Program (MP 11.0). (2011. június 10.). Online: https://infoter.hu/attachment/0011/10551_magyary_program.pdf

Mohácsi Györgyi: Mikor és mitől hatékony az e-learning? HR Portal, 2007. június 27. Online: www. hrportal.hu/hr/mikor-es-miert-hatekony-az-e-learning-20070627.html

Nemzeti Közszolgálati Egyetem: Megvalósithatósági tanulmány - KÖFOP-2.1.1-VEKOP-15 A közszolgáltatás komplex kompetencia, életpálya-program és oktatás technológiai fejlesztése (kedvezményezett: Nemzeti Közszolgálati Egyetem). 2016. Online: https://fejlesztesiprogramok.uni-nke. hu/document/fejlesztesiprogramok-uni-nke-hu/mt-211-nke-kofop-2016_03_03.original.pdf

Nemzeti Közszolgálati Egyetem: Megvalósithatósági tanulmány - KÖFOP-2.1.2-VEKOP-15 A jó kormányzást megalapozó közszolgálat-fejlesztés (kedvezményezett: Nemzeti Közszolgálati Egyetem). 2016. Online: https://fejlesztesiprogramok.uni-nke.hu/document/fejlesztesiprogramokuni-nke-hu/megvalosithatosagi-tanulmany-kofop-2_1_2.original.pdf

T/2241. számú törvényjavaslat a köztisztviselők jogállásáról szóló 1992. évi XXIII. törvény módosításáról. Online: www.parlament.hu/irom39/02241/02241.pdf 